NEI, M. (1973): Analysis of gene diversity in subdivided populations. Genetics 70: 3321-3323.

NEI, M. (1978): Estimation of average heterozygosity and genetic distance from a small number of individuals. Genetics 89: 583-590.

Oleghe, P. E. and F. K. Akinoufesi (1992): Gum yield of Acacia senegal as affected by soil and water potential and season of tapping. Nitrogen fixing Tree Research reports 10: 106-109.

OlnG'OTIE, P. A. S. (1992): Acacia tortilis (Forsk.) Hayne: A study of Genetic Diversity and Breeding Systems. Unpubl. D. Phil. Thesis. Oxford University, Oxford, England, pp. 117.

Peakall, R and P. E. SMouse (2006): GENALEX 6: genetic analysis in Excel. Population genetic software for teaching and research. Molecular Ecology Notes 6: 288-295.

Playford, J., J. C. Bell and G. F. Moran (1993): A major disjunction in genetic diversity over the geographic range of Acacia melanoxylon $\mathrm{R}$. Br. Australian Journal of Botany 41: 355-368.

ReED, D. H. and R. FRAnkham (2001): How closely correlated are molecular and Quantitative measures of genetic variation? A mata-analysis. Evolution 55: 1095-1103.

TRIEST, L. (2008): Molecular ecology and biogeography of mangrove trees towards conceptual insights on gene flow and barriers: A review. Aquatic Botany 89: 138-154.
WAChiRA, F. N., J. TANAKA and Y. TAKEDA (2001): Genetic variation and differentiation in tea (Camellia sinensis) germplasm revealed by RAPD and AFLP variation. Journal of Horticultural Science and Biotechnology 76(5): 557-563.

Williams, J. G. K., A. R. Kubelik, K. J. LivaK, J. A. RAFALSKI and S. V. TINGEY (1990): DNA polymorphisms amplified by arbitrary primers are useful as genetic markers. Nucleic Acids Research 18: 6531-6535.

Wolfe, A. D. and A. Liston (1998): Contributions of PCRbased methods to plant systematics and evolutionary biology, pp. 43-86. In: Molecular systematics of plants: DNA sequencing, edited by P. S. Soltis, D. E. Soltis and J. J. DOYLE, Kluwer, New York.

Yeh, F. C., R. C. YANG, T. B. J. Boyle, Z. H. Ye and J. X. MAO (1999): POPGENE 3.2, the User Friendly Shareware for Population Genetic Analysis. Molecular Biology and Biotechnology Center, University of Alberta, Edmonton.

Zietkiewicz, E., A. RAFAlKI and D. LABUdA (1994): Genome fingerprinting by Simple Sequence Repeat (SSR)-anchored polymerase chain reaction amplification. Genomics 20: 176-183.

Zobel, B. and J. TALBERT (1984): Applied Forest Tree Improvement. John Wiley and Sons, New York.

\title{
A New Breeding Strategy for Pinus radiata in New Zealand and New South Wales
}

\author{
By H. S. DungeY ${ }^{1), *}$, J. T. Brawner ${ }^{2), 3)}$, F. Burger ${ }^{4)}$, M. Carson ${ }^{5)}$, M. Henson ${ }^{6)}$, P. Jefferson ${ }^{7)}$ and A. C. Matheson ${ }^{8)}$
}

(Received $13^{\text {th }}$ November 2007)

\begin{abstract}
A new breeding strategy is presented for the Radiata Pine Breeding Company, a New Zealand based research consortium, that drives the breeding program for Pinus radiata for both the New Zealand and New South Wales

1) Scion, Private Bag 3020, Rotorua, New Zealand.

2) Horizon2, 1943 State Highway 30, Te Teko, RD 2 Whakatane, New Zealand.

3) Present address: CSIRO Plant Industry, 11 Garnet Street, PO Box 873, Cooroy, Queensland 4563, Australia.

4) Carter Holt Harvey Forests Ltd, Ngahere house, Vaughans Road Rotorua.

5) Forest Genetics, 34 Parawai Rd, Rotorua, New Zealand.

$\left.{ }^{6}\right)$ Forests NSW, PO Box 100 Beecroft NSW, 2119, Australia.

7) Radiata Pine Breeding Company, 430 Ngongotaha Road, Ngongotaha, Rotorua, New Zealand.

8) CSIRO Plant Industry, PO Box E4008 Kingston, Canberra, 2604, ACT, Australia.

*) Communicating author: HeIDI S. Dungey. Ph +64-7-3435629,

Fax +64-7-348 0952. E-Mail: heidi.dungey@scionresearch.com
\end{abstract}

based Australian forest plantation industry. The new strategy builds on the existing base for $P$. radiata, and on the last strategy review in 2000.

The new strategy comprises a large open-pollinated (OP) Main Population (MP) with 500 female parents and two sublines (250 female parents per subline). The MP will be tested using alpha designs, single-tree plots and incomplete blocks to maximise efficiency. Each subline will be tested on four sites, geographically distant from the other subline. The MP will be managed in discrete generations. Selection of the next generation will be using a combination of backward and forward selection, but the strict control of inbreeding with identified lineage will rely on the development of parental reconstruction for OP progeny. There are alternatives to this, however, such as estimating the group coancestry and accepting some additional increase in inbreeding. This is a new and significant departure from previous breeding strategies for $P$. radiata in New Zealand.

There will also be a single, small Elite Population (EP), tested $50 \%$ as progeny and $50 \%$ as clones. Twenty 
four parents will be tested each year as clones and 24 as seedling progeny with some overlap between the two. It is expected that the clonal population will capture the greatest gains in traits with low heritabilities, and the half-sib progeny will capture the greatest gains in traits with high heritabilities. The two sublines will be maintained in the EP, and breeding will be managed as a rolling front with trials established every year, while trials of the MP will be established every 10 years.

Key words: Australia, clones, genetic gain, sublining, mating system.

\section{Introduction}

Pinus radiata D. Don. is the principal plantation species in New Zealand, occupying around 1.63 million ha, over $89 \%$ of the current plantation resource (ANON., 2006). The species has five distinct populations in its natural distribution, including Cedros and Guadalupe Islands off the coast of Mexico, and Cambria, Monterey and Año Nuevo on the California coast, U.S.A. (BURDON and Miller, 1992; LAVERY and MEAD, 1998). In New Zealand, plantation $P$. radiata is based largely on a breeding population derived from land races, originating primarily from the Monterey and Año Nuevo populations (BURDON and MiLler, 1992). Since the first selection and breeding of $P$. radiata was undertaken over 50 years ago, the species has been subjected to at least two cycles of selection (JAYAWICKRAMA and CARSON, 2000; SHELBOURNE et al., 1986). Reviews of how the species has been bred have also been presented several times since the development of a breeding programme (see JAYAWICKRAMA and CARSON, 2000). The third generation of Pinus radiata is now being developed for members of the Radiata Pine Breeding Company, for future use in both New Zealand and Australia. This is a major step forward for this species, which has been selected for growth and form since the 1950's, for resistance to Dothistroma pini since 1983 (CARSON and CARSON, 1986) and for wood quality (density) since 1975 (BURDON, 2008a, b; JAYAWICKRAMA, 2001; JAYAWICKRAMA and CARSON, 2000).

Breeding $P$. radiata was originally initiated in the R\&D section of the New Zealand Forest Service, which later became a limited liability company, the New Zealand Forest Research Institute. In the mid 1980's, a breeding cooperative was formed with industry partners. This cooperative then itself became a limited liability company in 2001, with full germplasm ownership (R. Burton pers. comm.; Burdon, 2008a). The most recent change for New Zealand $P$. radiata is the formation during 2004 of the Radiata Pine Breeding Company (RPBC), a research consortium with joint industry and government funding. The RPBC is now a consortium between multiple research providers including Scion (formerly Forest Research), the forest industry, and with the University of Canterbury as an associate member. The formation of the Radiata Pine Breeding Company Research Company provided a unique opportunity for revising, updating and implementing the most recent strategy, summarised by JAYAWICKRAMA and CARSON (2000).

The strategy presented here is the result of a review initiated in 2004, shortly after the formation of the
RPBC. The review was aimed at obtaining an external evaluation of the existing breeding strategy (JAYAWICKRAMA and CARSON, 2000), to build upon and move forward with the existing genetic population.

This paper outlines the background and gain simulations undertaken leading up to the strategy review, briefly describes the review process, and presents the new breeding strategy structure.

\section{Summary of the previous strategy}

The JAYAWICKRAMA and CARSON (2000) strategy was the last major revision of radiata pine breeding in New Zealand. The structure of this strategy was divided into a MP and a number of "breeds". All populations were partitioned into two sublines, to minimise inbreeding. Control pollinated (CP) seed orchards, with crossing between the sublines, were assumed to be the primary path for deployment (CARSON, 1986). The emphasis within the main was on recurrent selection for GCA. Genotype $\mathrm{x}$ environment interaction was not considered to be sufficiently important to warrant regionalised breeding programmes (CARSON, 1990; JAYAWICKRAMA and CARson, 2000). Four breeds (Growth and Form, Dothistroma Resistant, Clear Cuttings [a breed with moderate to long internodes and low spiral grain angle] and Structural Timber; JAYAWICKRAMA and CARSON, 2000) were formed from pre-existing populations discrete from the MP (including: Dothistroma Resistant, High Wood Density and Long Internode populations) and from selections using breeding goals established for growth, high wood density, clear cuttings and structural timber. A population containing Guadalupe provenance material was also to be integrated into the MP (Figure 1).

The main traits considered for selection were growth, form, wood density, and needle retention (in some series). Internal checking and spiral grain were considered mainly to eliminate inferior trees. Some selections were also made for increased internode length and reduced branch size.

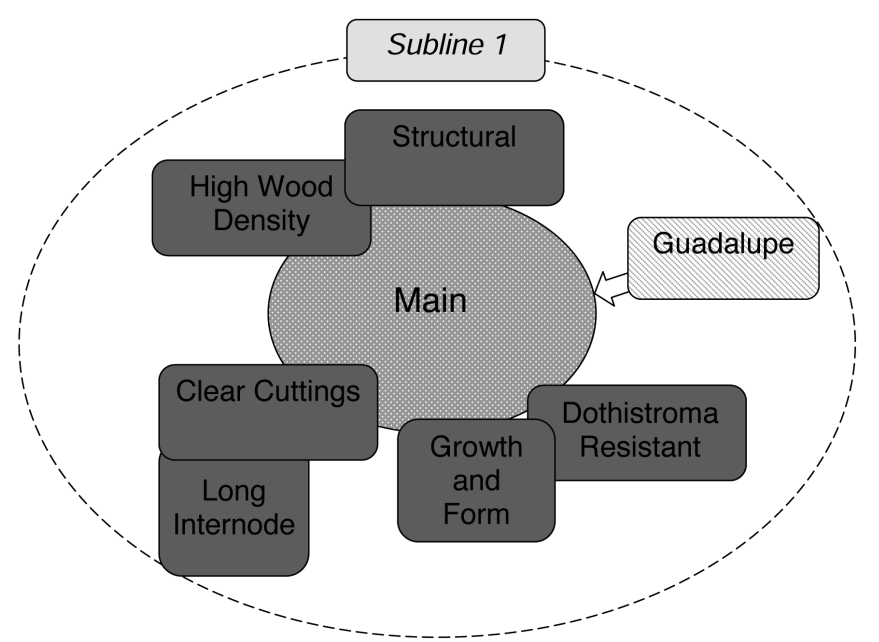

Figure 1. - Schematic diagram of the JAYAWICKRAMA and CARSON (2000) strategy (adapted from JAYAWICKRAMA and CARSON 2000). Only one subline is shown, although the strategy is comprised of 2 . Both sublines have exactly the same structure. 
The second generation MP was produced and established at three sites in 1992 to 3, with 83 pair-crosses involving 103 parents. Only one site survived an outbreak of Helicoverpa caterpillars. This trial series, named the 'Big Bang' attempted to bring together a number of disjunctive selection series, incorporating land race selections, usually from different regions within New Zealand, but selected across different years. Two additional land race selected populations (885 and 888 series) are being incorporated into the MP. A further 125 parents (male and female), including some Australian selections from New South Wales have been established but are as yet too young for a meaningful assessment. Mating for this second generation MP was based on double-pair mating or pair-crosses (JAYAWICKRAMA and CARSON, 2000). JEFFERSON (2005) identified that the status number of the Main and EPs were 29.3 and 32.9 for sublines 1 and 2 respectively.

In 2002 and 2003, 50 forward selections from the Big Bang were chosen and supplemented with selections from the Dothistroma (43) and High Density (46) EPs (Stovold and JefFerson, 2004). Open Pollinated (OP) seed was collected from all the ortets selected within the trials and the first seed was sown in winter 2004, with trials established during 2005.

The breeding strategy also involves a $P$. radiata gene resource, known as the Gene Resource Population (GRP). This includes native population material from the five main provenances of radiata pine. In addition, it includes land race material, which has developed over a number of generations within New Zealand and Australia. The populations available include:

- OP progeny from 13 native mainland populations, each with about 40 female parents per native population, 513 selections in all, planted in provenance trials and in approximately 183 ha of block plantings established 1980 to 89.

- Guadalupe island: 67 selections from OP progeny tests, currently tested as 70 full-sib crosses in 2 sublines, and available for infusion into the MP.

- Cedros Island: 30 selections made, originally from two stands present on Cedros Island. Crossed in a doublepair mating design, with seed sown in 2004.

Other gene resources that may be available in the future include resources from other $P$. radiata breeding programs. This may be through the Southern Tree Breeding Association (STBA), which manages the majority of $P$. radiata breeding in Australia, based at Mt Gambier in South Australia (Borralho and DutKowski, 1998; Powell et al., 2004; 2005; White et al., 1999). Forests NSW, historically a part of the STBA joined the RPBC in 1990 after a severe shortage of seed in Australia, and a critical review of plantations determined that climate and soil types were more similar in New Zealand than in South Australia (JOHNSON et al., 2008). Other sources include material from breeding programmes in Chile, South Africa and Spain (LAVERY and Mead, 1998). Pinus radiata also exists in the natural populations in California, Cedros and Guadalupe islands. Nevertheless, material from many of these countries is restricted due to the presence of pine pitch canker and the strict quarantine rules for entry of seed into New Zealand (e.g., see DiCK, 1998; ORMsBy, 2004).

\section{Background research}

Two main areas of research were undertaken prior to the revision of the breeding strategy. First, deterministic simulations examined the potential gains that cloning may bring to the breeding strategy. Second, whether breeding values predicted from clones were comparable to those predicted from seedling progeny trials was also investigated to determine the breeding success under a cloning scenario. Brief summaries of the outcomes of these research areas are given below, as they provide important background information.

\section{Maximising gains: the basis for a proposed breeding strategy}

A deterministic simulation study was undertaken to compare gains from clones versus seedlings (progeny) from OP, polycross and full-sib families in large MP and small EPs (Shelbourne et al., 2007). Genetic gain (as the percent improvement in the mean of a single trait) was predicted for a range of heritabilities and population sizes for cloned versus seedling breeding populations using G-Assist (VERRYN and SNEDDEN, 2000).

Gains when using OP and polycrosses in the MP (using within-family selection) were larger than when using Control Pollination (CP) (SHELbourne et al., 2007). Cloning 25 seedlings per family (produced from $\mathrm{OP}$, polycrosses or $\mathrm{CP}$ ), with a few cuttings of the original seedling, gave better predicted gains than from an equivalent number of seedlings per family, at least up to a heritability of 0.5 (which includes most $P$. radiata traits). Using OP crosses in the MP resulted in shorter testing cycles. In addition, OP crosses meant that there was no grafting of parents into archives for $\mathrm{CP}$, which is cheaper than a full CP program. Above all, cloning of the progeny of the small EP enabled the selection of the best clones for seed orchards without the costly time consuming step of further progeny testing. Furthermore, managing one Elite test as a clonal archive would allow CP for the next cycle of Elite breeding to be undertaken without delay.

A possible new strategy and plan for developing the existing $P$. radiata breeding programme was proposed in the light of these findings (SHELBOURne et al., 2007). This would involve the rapid creation of an expanded MP with at least 400 OP families from the best forwardand backward-selected parents available, as well as further selections from unplanted pair-cross family seedlots, and OP progeny tests of selections from the surviving 1993 'Big Bang' trial. Cloning was rejected for use in this generation of the MP, because the cost and delay in doing so was prohibitive. A fully cloned full-sib EP was also proposed with forward selection and clonal tests that could be later converted into clonal seed orchards to enable rapid deployment and reduce the length of the breeding cycle. The proposed strategy was used as a basis for the strategy review process. 


\section{Clonal versus seedling breeding values.}

The majority of selection in the breeding program has been based on the backward selection of parents for general combining ability (GCA) after extensive progeny testing (JAYAWICKRAMA and CARSON, 2000). Before clonal testing would be considered by RPBC members, it was necessary to demonstrate that clonal breeding values would be just as reliable as breeding values based on progeny or testing for GCA. KUMAR (2006) examined the results of a clonal test propagated by fascicle cuttings, with the performance of their OP offspring in a progeny test. The correlation of the female parent's breeding values when planted as clones or OP progeny indicated that the clonal breeding values estimated in the clonesin-families trials were adequate predictors of their offspring-based breeding values in the OP trials. However, the size of the correlation depended largely on the size of the estimated heritability concerned; the higher the heritability, the higher the correlation. This is likely to be associated with poor estimation of means for lower heritability traits. However, further work is needed to confirm this. Nevertheless, the good news was that the breeding values estimated from the clonal trials appeared to be adequate.

\section{Influence and experience from other programmes.}

Key issues for breeding strategy include the control of inbreeding (WILliAMS and SAVOLAINEN, 1996; Wu et al., 1998), mating type (KING et al., 1998; DANUSEviCIUs and LINDGREN, 2005; CotTERILl, 1989; BorRAlHo and DutKowski, 1998), population size and/or status number (e.g. DANusevicius and LindGREN, 2005; LindGREN et al., 1996), time and cost (DANUSEVICIUS and LINDGREN, 2005) and aims of the program (see WHITE and CARSON, 2004). Optimal solutions vary with species, region and breeding objective, although reciprocal selection for general combining ability is favoured in many conifer breeding programs (WHITE and CARSON, 2004).

Breeding strategies in Australia and New Zealand are both influenced by Cotterill (COTTERILL, 1986, 1989; COTTERILl et al., 1989) and the concept of nucleus breeding. New Zealand had already developed multiple-population strategies, driven for example by the early need for the development of a Dothistroma Resistant population as early as 1983 (CARSON and CARSON, 1986). However, the concept of nucleus breeding strategies further influenced the structure of the breeding population. This is evident through the existence of the 'elite' populations (JAYAWICKRAMA and CARSON, 2000). New Zealand was also strongly influenced by Danish tree breeding by the leadership of the breeding group for many years by Ib Thulin (e.g. THULIN, 1957) as well as Northern American ideas (e.g. White et al., 1993, 1999; MCKEAND and BRIDGWATER, 1998; MAHAlOviCH and BRIDGWATER, 1989), and concepts of adopting discrete generations and structured sub-lining (JAYAWICKRAMA and CARSON, 2000; BURDON and NAMKOONG, 1983). In addition to CoTTERILL (1986) and CotTerill et al. (1989), Australia was influenced by more traditional breeding schemes as discussed by White et al. (1999). More recently the program was influenced by the ideas of Nuno Borralho in the late 1990s and the arrival of 'rolling front' strategies, involving annual testing cycles (BORRALHO and DuTKOWsKI, 1998).

LAMBETH et al. (2001) strongly influenced New Zealand breeders in their paper on polymix breeding, using molecular markers to identify the male parents of progeny though paternity analysis. This presented a method to simplify and reduce the costs of progeny testing, while still keeping control of inbreeding in forward selection. KUMAR et al. (2005) determined that parental reconstruction for most progeny was possible through markers in polycross progeny in radiata pine. Technical difficulties remain, and ambiguous parentage results remain a problem due to relatedness (e.g. LAMBETH et al., 2001). In the next decade, New Zealand will end an era of unimproved forests and move to harvesting only improved breeds. This will limit the number of possible contributing male parents. The top 50 parents of the $P$. radiata breeding population have already been genotyped for other studies (P. WILCOX pers. comm.). However, the number of male parents will more than likely be less than 50 parents in a single polymix, where all parents are known.

In addition, as discussed by KUMAR (2006), various simulation studies had indicated the advantages of cloning in the breeding population (SHAW and HooD, 1985; JEFFERSON and WEAVER, 1997; Rossvall et al., 1998; DANusevicius and LindGRen, 2002). These studies were followed by SHELBOURNE et al.'s (2007) empirical simulations. Results confirmed the likelihood of additional gains through cloning in the breeding population. Simulations have also recently shown that variation across individuals in success of vegetative propagation by somatic embryogenesis does not necessarily lead to reduction in gain (LSTIBÜREK et al., 2006).

Recently published work on breeding strategies has highlighted some new ideas. Gains are likely to be enhanced using positive assortative mating (PAM; LSTIBÜREK et al., 2004a). Stratification of sublines by using positive assortment of breeding values to organise sublines, has been shown in simulations to lead to increased genetic gains (RUOTSALAINEN and LINDGREN, 2000). Simulations have also indicated an optimal breeding population size between 30 and 70 individuals (DANUSEVICIUS and LindGren, 2005). Smaller populations suited more intensive and efficient breeding programs for traits with higher heritability, high phenotyping costs and a low priority to gene diversity with a small overall budget.

\section{The review process}

In July 2005, a workshop was held to develop a new breeding strategy for the RPBC. The review was based on information from the JAYAWICKRAMA and CARSON (2000) strategy and the information and recommendations from the research results outlined above. A panel of international experts in breeding strategy was invited to participate in the review. Beginning with the MP, the structure and some operational elements of the breeding strategy were put to open debate. The strategy is therefore one built on consensus among participants at the 
workshop. A further one day workshop was held in Rotorua, New Zealand to finalise some details of the EP breeding strategy. The outcome of the workshops and details of the new strategy are outlined below.

\section{The new RPBC radiata pine breeding strategy}

\section{Main Population MP}

The MP will be cycled in discrete generations and comprised of 2 sublines. Each subline will consist of 250 female parents and will be named RED and WHITE respectively (Figure 2). Inbreeding will be contained within sublines and outcrossing across superlines will always be available for deployment purposes. Each subline will be tested as OP progeny on four sites with twenty individuals per family per site in a single-tree plot design.

The MP will generally use an OP testing strategy although the first round of tests will be constructed from what material is available now for testing. This includes a combination of OP progeny from various sources, including forward selections and CP progeny from the previous JAYAWICKRAMA and CARSON (2000) - based crosses. More detail is given in Table 1.

An OP strategy ensures that the process is relatively inexpensive, is able to be accomplished without grafting and crossing, which will reduce time taken for generation turnover and will keep the process relatively flexible.

Risks of selecting sibs as forward selections from OP populations are real, but with the developing DNA pedigree reconstruction (paternity analysis for trees), these risks may be mitigated. The advantage of this system is that it allows MP trials to be used for both GCA testing and forward selection at the same time. A recent study (KUMAR et al., 2005), reconstructed LAMBETH et al. (2001)'s parental analysis in Pinus taeda, suggested that molecular markers could successfully be used for pedigree reconstruction in polycross families. However, further research is required to test this approach in $\mathrm{OP}$ families.

The decision to move towards an OP strategy was based on a few main assumptions. First, it was assumed that parental reconstruction for forward selection would be sufficiently developed by the end of this testing cycle. It was also assumed that some increase in inbreeding would be acceptable in the MP, particularly if it was assumed that the current low status numbers in the sublines (29.3 and 32.9) (JEFFERSON, 2005), would be boosted significantly by the infusion of more land race selections from the 885 and 888 series. It was also assumed that before a new testing cycle was begun, simulation work would have been undertaken. Specifically, simulations are needed to determine the effects of inbreeding, the gains possible and the advantages and disadvantages of an OP versus a polycross or CP approach. Further motivation for the move to an OP strategy in the MP was the reduction of costs incurred up-front in controlled-crossing programs, a high priority for the industry-led breeding company. Future testing cycles may adopt any one the crossing strategies, depending on the outcomes of this research.

If parental reconstruction techniques are not successful, one alternative approach is to estimate group coancestry and accept some additional inbreeding, at least within sublines. For example, Rossvall et al. (1998) identified in their breeding strategy simulation using double-pair mating over 10 generations, that as long as each population contained at least 24 individuals, increases in group coancestry, inbreeding and inbreeding depression and the loss in additive gain did not appear to have an effect on the accumulation of gain per generation. However, status number did reduce from 48 to 8.1. Rossvall and Mullin (2003) reported that positive assortative mating using 48 trees crossed to

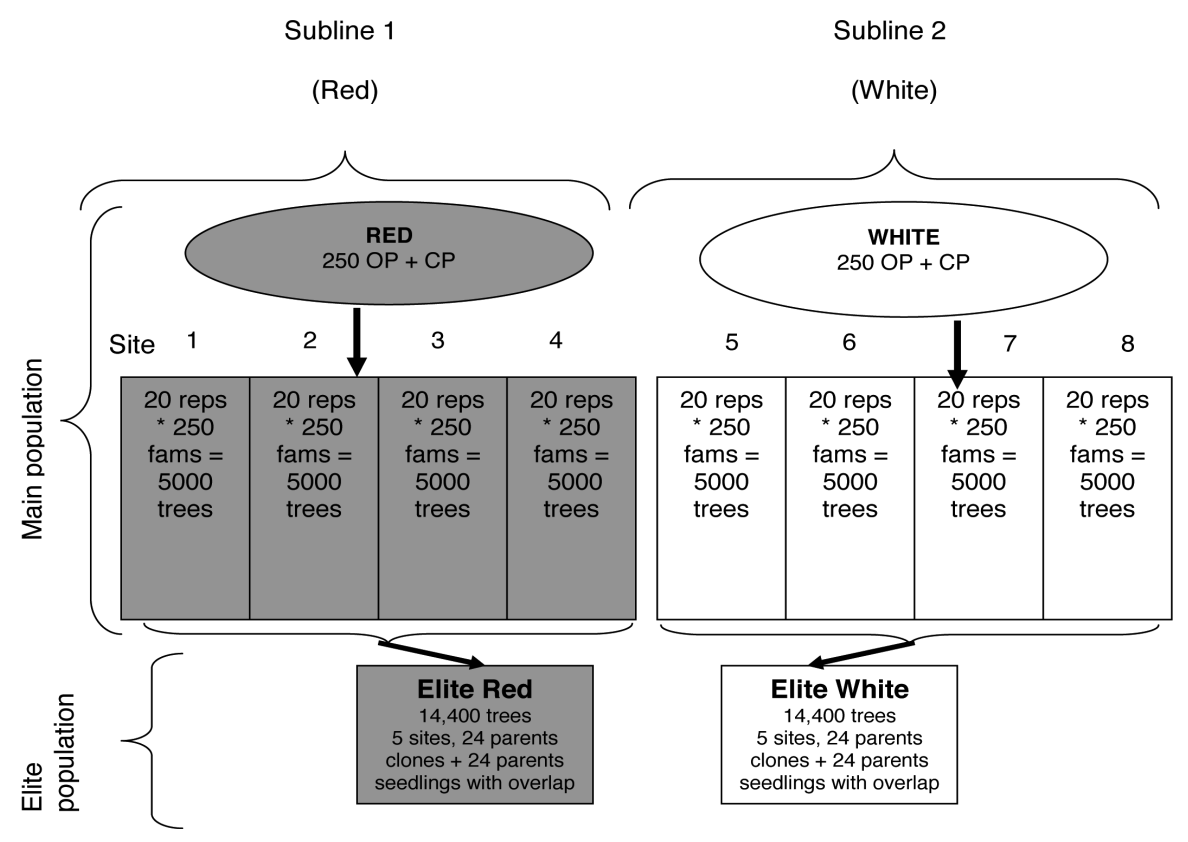

Figure 2. - Schematic diagram showing the RPBC Main and Elite breeding populations. 
Table 1. - Provisional list of seed sources for the RPBC Main breeding population testing.

\begin{tabular}{llcc}
\hline Seed sources & & $\%$ & Number of parents \\
\hline Open pollinated & RPBC forward selections & 40 & 200 \\
& NSW & 7 & 35 \\
& Australian seed sources & 10 & 50 \\
& Best native population selections & 2 & 10 \\
Control pollinated & Old strategy control-pollinated seed ${ }^{*}$ & 20 & 100 \\
& Orchard managers & 13 & 65 \\
& NSW & 3 & 15 \\
& Australian seed sources & 5 & $\mathbf{2 5}$ \\
& Total & 100 & 500
\end{tabular}

* Seed from the JAYAWICKRAMA and CARSON (2000) strategy that has not been used in previous trials.

produce 24 full-sib families with clonal selection was optimal when compared with random mating. They also noted that any effect of inbreeding was eliminated by genetic recombination in the seed orchard. Perhaps a combination of double-pair mating with positive assortative mating and coancestry restrictions would be a good alternative. Maintaining sublines for the elimination of inbreeding in the seed orchards would also make sense. Further simulations will be undertaken to test alternatives as the strategy progresses.

Infusions into the MP from the Gene Resource Population will involve identifying the best 10 native population selections. These will be tested as progeny as part of the OP progeny from the 500 selections in the breeding population trials. Infusions of Gene Resource material will continue in the same way in subsequent generations.

\section{Testing the Main population}

The MP will be tested in eight field trials, four trials for each superline, designed to connect the different selection series previously not tested together (JAYAWICKRAMA and CARSON, 2000) and evaluate new forward selections across a range of sites. The number of sites is larger than the current standard of three, mainly due to the industry's requirement that the tests to be represented across a larger number of environments. CARSON (1991) indicated genotype $x$ environment interaction was insufficient to warrant regionalised breeding programs within NZ, although this interaction has been found to be statistically significant in a number of stud- ies (Burdon, 1971; CARson, 1991; Burdon et al., 1997). Now New South Wales (NSW) is part of the RPBC further details of interactions with NSW and even within NSW are required (e.g. KUMAR et al., 2004b). Several studies are currently underway to determine the genotype $x$ environment interaction within NSW and between NSW and NZ (M. HENSON pers. comm.).

Ideally, superlines should be planted geographically distant from each other in order to keep them genetically distinct, and avoid pollen contamination between superlines. This will enable the continuation of an OP breeding strategy in the next generation.

The number of female parents to be tested is targeted at 500 , or 250 per subline. The number of individuals per site per family will be 20 , with a total of 80 across all four sites (Table 2). The field design will be based on an incomplete block design, using single-tree plots. The change from sets-in-replicates to an incomplete block design follows research that has shown the superior efficiencies of these designs, particularly alpha designs, over more traditional field designs (WILLIAMs et al., 2002; YoNG-BI FU et al., 1998).

\section{Elite Population EP}

Rather than a few distinct breeds in distinct populations as proposed by JAYAWICKRAMA and CARSON (2000), the new strategy will have only one EP, consisting of $50 \%$ clones and $50 \%$ seedlings from CP crosses. The population will managed intensively and follow a 'rolling front' approach, with trials going to the field every second year, adapted from the 'rolling front' strate-

Table 2. - Size and composition of genetics trials of the Main population.

\begin{tabular}{ccccccc}
\hline & & $\begin{array}{c}\text { Parents } \\
\text { tested }\end{array}$ & $\begin{array}{c}\text { Seedlings/ } \\
\text { Samily/site }\end{array}$ & $\begin{array}{c}\text { Seedlings/ } \\
\text { Family (all sites) }\end{array}$ & $\begin{array}{c}\text { Trees/ } \\
\text { site }\end{array}$ & $\begin{array}{c}\text { Trees - } \\
\text { (all sites) }\end{array}$ \\
\hline Main Population & $\mathbf{8}$ & 500 & 20 & 80 & 5,000 & 40,000 \\
\hline
\end{tabular}


gy outlined by BorRALHo and DuTKOwski (1998). This 'rolling front' approach implies that every year there will be crosses, testing and selection activities, rather than a single discrete generation. This approach was selected to both balance the work program and increase the delivery of gain per annum.

The two superlines present in the MP will be maintained in the EP. These will be defined as the Red and White Elite sublines and comprise a minimum of 24 select parents per subline (Figure 2). Within each subline 24 parents will be used to create the cloned progeny, and 24 parents used to create the seedling progeny. There will be some overlap of parents between the clone and seedling populations. The final number and arrangement of parents will depend on what is available and flowering amongst the highest ranking candidates.

The adoption of cloning in the EP is an attempt to capture the maximum gain from forward selections in these breeds, as recommended by SHELBOURNE et al. (2007). The use of seedling progeny will enable the greatest gains to be captured for traits of higher heritability (i.e., more individuals per family and more families will be tested). The clones, on the other hand, will enable better prediction of genetic worth for the traits with lower heritabilities (e.g. growth, form). The presence of the clones will also allow for some destructive testing, along with providing an opportunity to better understand clone $\mathrm{x}$ environment interaction.

In addition to the sublines, there will be a small number of pre-deployment Elites created from the best parents in each superline, selected from previous Elite testing. These crosses will be largely opportunistic and vary in number, but are expected to produce about 10 families. The production of progeny in this pre-deployment population is aimed at providing connectedness between the sublines and to provide consortium members with screened genotypes with the potential for commercial deployment or for use in commercial orchards, or as commercial clonal varieties.

For the first round of crossing in the EPs, genetic analyses will identify the top parents using a selection index. These parents will be mated in circular, incom- plete factorial designs, to produce 14,400 trees for testing every second year. Individual-trait thresholds to meet the requirements of being an 'Elite' parent are yet to be developed. Mate selection criteria also need to be developed to optimise genetic gain. The build up of relatedness in the rolling front strategy adopted for the $\mathrm{EP}$ may make mate selection for progeny testing more difficult as the rolling front advances.

Rolling front strategies have been adopted for radiata pine breeding in the Southern Tree Breeding Association (STBA) (BorRAlHo and DutKowski, 1998; Powell et al., 2004; 2005). One of the most important aspects of this type of strategy is to maintain connectedness between the different tests, or breeding values will be biased (e.g. see MARK and MASDEN, 2002). Between a 10 and $20 \%$ connectedness has been the aim in forestry, based largely on experience from animal breeding studies (e.g. KueHn, 2005; HANOCQ et al., 1996; LALOË et al., 1996; MATHUR et al., 2002). This means that about $20 \%$ of fullsib families, seedlots, parents, or families with relatedness must be common across all EP trials. However, this does not imply that all of the ' $20 \%$ ' connecting material must be the same across all tests. A review of rolling front strategies and maintaining efficient connectedness is needed to ensure that the best of these strategies will be successfully adapted to the RPBC situation.

\section{Testing the Elite Population}

For each set of Elite families produced from the 48 parents ( 24 parents per superline), 20 clones per family and 2 ramets per clone will be tested across 5 sites (equivalent to 9,600 plants). For another 48 families, 20 seedlings/family/site over 5 sites will be tested (equivalent to 4,800 plants). The total number of plants required to plant 5 sites would then be 14.400 .

The EP will be tested across five sites, $50 \%$ as seedlings and $50 \%$ as clones. The composition of Elite trials will be as follows (see also Table 3):

1. Seedlings: 48 families, with 20 progeny per family tested over five sites, giving a total of 4,800 trees. The seedling tests are aimed at capturing gain through forward selection, in traits with high heritability such as wood quality variables.

Table 3. - Size and composition of genetics trials of the Elite population. Note: the pre-deployment crosses are $100 \%$ clonally replicated.

\begin{tabular}{|c|c|c|c|c|c|c|}
\hline & Sites & Families & $\begin{array}{c}\text { Clones or } \\
\text { seedlings/ } \\
\text { Family }\end{array}$ & $\begin{array}{l}\text { Ramets/ } \\
\text { Clone }\end{array}$ & $\begin{array}{l}\text { Trees/ } \\
\text { Site }\end{array}$ & $\begin{array}{l}\text { Trees - } \\
\text { all sites }\end{array}$ \\
\hline \multicolumn{7}{|l|}{ Elite clones } \\
\hline (Red and White superlines) & 5 & 48 & 20 & 2 & 1920 & 9,600 \\
\hline \multicolumn{7}{|l|}{ Elite seedling } \\
\hline (Red and White superlines) & 5 & 48 & 20 & 1 & 960 & 4,800 \\
\hline Elite pre-deployment crosses & 5 & 10 & 20 & 2 & 400 & 2,000 \\
\hline Total plants & & & & & 3,280 & 16,400 \\
\hline
\end{tabular}


Table 4. - Advantages and disadvantages of various propagation systems.

\begin{tabular}{|c|c|c|c|c|c|}
\hline Propagation system & & $\begin{array}{c}\text { Elongated fascicle } \\
\text { cuttings }\end{array}$ & $\begin{array}{l}\text { Organogenesis } \\
\text { (axillary) }\end{array}$ & $\begin{array}{l}\text { Organogenesis } \\
\text { (cryo'd cots*) }\end{array}$ & Embryogenesis \\
\hline Multiplication rate & & Moderate & High & High & High \\
\hline Efficiency of Genotype Capture & & High & Moderate-high & Moderate-high & Low and variable \\
\hline Cost & & Low & Moderate & Moderate & High \\
\hline \multirow{3}{*}{ Storage options } & Hedging & Yes & & & \\
\hline & Cool storage & & Yes & & \\
\hline & Cryo-preservation & & Yes (?) & Yes & Yes \\
\hline
\end{tabular}

* cryopreserved cotyledons.

2. Clones: 48 families, with 20 clones per family, with 10 ramets per clone tested across 5 sites $(2$ ramets per site per clone) giving a total of 9,600 trees. The clones are aimed a capturing gain in traits with low heritability.

3. Pre-deployment crosses will also be created by crosses between the 'White' and 'Red' sublines. This population will be $100 \%$ cloned and will test about 10 families, 20 clones per family and 2 ramets per clone tested at each site, giving a total 2,000 trees across all sites.

Trials will be based on an incomplete block design, with two resolvable reps and 24 incomplete blocks per resolvable replicate. It is intended that the clones and seedlings will be tested together. At the family level, a randomised complete block design will be used, and at the clone-within-family level an incomplete block design within each replicate will be used. Trials are scheduled to go out every other year. It may be more practical, however, to put out trials every year, focusing on a separate subline and/or breeding objective each time.

Selection of the five testing sites must represent the main areas of deployment. This would need to include at least two sites in the North Island of New Zealand, at least one South Island of New Zealand and a site in Australia. At least one site in the central North Island of New Zealand is recommended, because this area has previously proven to be ideal for maximising gains across NZ sites (CARSON, 1990).

\section{Deployment}

The optimal deployment option for maximising gain per unit time for this strategy would be through deploying tested EP clones as commercial clonal varieties. A next-best option is the conversion of an EP clonal test into a clonal seed orchard after rogueing (SHELBOURNE $e t$ al., 2007). However, the mandate of the RPBC does not include deployment. Individual member organisations or companies in the RPBC are expected to adopt a number of different approaches according to their individual needs. Some of the likely options are:

- Planting of an additional EP test for rogueing and conversion to a clonal seed orchard according to the requirements of the individual consortium member.
Seed can be used directly from this orchard for production of seedlings with high ratings for deployment.

- Selection of clones and individuals with the best combination of traits suited to the individual needs of the members. Clonal testing of these selections or of clones from the same families across the company's estate, followed by targeted deployment of the best material. Maintenance of juvenility in the selections is required whilst they are tested.

- Creation of highly-rated CP seed selected to suit the requirements of the members, with bulking up of this material through clonal propagation. Deployment of clones using family forestry.

- Creation of mid-rated CP seed selected to suit the requirements of the member company. Deployment through seedlings.

\section{Gene Resource Population GRP}

The Gene Resource Population will be managed to ensure maintenance of genetic diversity. Several options for turning the rotation-aged populations over were put forward by STOVOLD et al. (2004). The recommended option involved collecting OP seed and advancing the genetic material in a pair of 20 ha plots per provenance, to be cycled every 30 years.

The option of using OP seed for advancement is simple and relatively inexpensive (STOvold et al., 2004). However, the amount of pollen contamination is unknown. Research is needed to support finding 'private' alleles from each of the native provenances in order to determine how important and large the pollen contamination issue will be for the maintenance of genetic diversity

\section{New technologies}

Although research is underway in New Zealand using molecular technologies in $P$. radiata (BALL, 2001; KUMAR and RICHARDSON, 2005; KUMAR et al., 2000, WILCOX et al., 1997; Wilcox et al., 2007), molecular technologies such as marker aided selection or gene assisted selection have not been targeted for use in this breeding strategy apart from their use in pedigree reconstruction. Pedigree reconstruction (parental analysis) is a technology that is already in use in some breeding programmes (RIBEIRo et al., 1998) and will be a vital tool for control- 
ling inbreeding in the MP discussed here. In addition, linkage disequilibrium (LD) is likely to give some important genetic information on inheritance that is not available in a traditional breeding programme (KUMAR et al., 2004a). Molecular genetics research is moving forward with new applications even for population genetics of natural populations (e.g. BLOUIN, 2003). Linking these ideas and methods from molecular biology with quantitative breeding methods will be imperative to progress the radiata pine breeding programme into the future.

\section{Conclusions}

A new breeding strategy for radiata pine has been developed for the Radiata Pine Breeding Company. The strategy has attempted to take a significant step forward, and has adapted the structures from the old strategy in order to capture more gain and turn over generations. New concepts include the use of cloning in the Elite, and the OP MP with pedigree reconstruction. The strategy revision has highlighted some key research areas and specific research topics. The need for a structured, well-managed and accessible database accompanied with more regular estimation of breeding values for breeding purposes was also highlighted. This review will allow the RPBC to move forward, and in conjunction with research, achieve gains that will bring a high economic return to shareholders.

A strategy of this kind will not be optimal for all species and all circumstances. Any adaptation of this strategy to other species and other growing regions will require careful evaluation. The strategy presented here is based on a consensus between science and the needs of industry shareholders in the breeding company. The strategy is therefore optimised to meet its obligations to both shareholders and science.

\section{Acknowledgements}

This project was funded by the newly formed Radiata Pine Breeding Consortium, and builds on the experience of all of its shareholders. The authors have drawn on this experience in the writing of this document. Thanks to Mike Menzies for contributions to the section on clonal replication. Thanks to SALLY GARNER for formatting. Thanks to Scion for providing additional support to finalise the publication of this paper.

Thanks to the participants at the Noosa workshop, including the RPBC subcommittee and four international experts. The international experts were: Dr. MARK Dieters (University of Queensland), Prof. Tim White (University of Florida), Dr. STEVe VerRYN (CSIR) and Dr. LuIs APIOLAZA (Forestry Tasmania, now University of Canterbury).

\section{References}

AnON. (2006): New Zealand Forest Industry Facts and Figures 2005/2006. New Zealand Forest Owners Association, Wellington, New Zealand. www.nzfoa.org.nz or www.nzforestry.co.nz.

BALL, R. D. (2001): Bayesian methods for quantitative trait loci mapping based on model selection: approximate analysis using the Bayesian Information Criterion. Genetics 159: 1351-1364.
Blouin, M. S. (2003): DNA-based methods for pedigree reconstruction and kinship analysis in natural populations. Trends in Ecology and Evolution 18: 503-511.

Borralho, N. M. G and G. W. DutKowski (1998): Comparison of rolling front and discrete generation breeding strategies for trees. Canadian Journal of Forestry Research 28: 987-993.

BuRDon, R. D. (1971): Clonal repeatabilities and clone-site interaction in Pinus radiata. Silvae Genetica 20: 33-39.

BuRDON, R. D. (2008a): Breeding radiata pine - historical overview. New Zealand Journal of Forestry 52: 4-6.

BuRDON, R. D. (2008b): Branching habit in radiata pine breeding goals revisited. New Zealand Journal of Forestry 52: 20-23.

Burdon, R. D. and G. NAMKOONG (1983): Multiple populations and sublines. Silvae Genetica 32: 221-222.

Burdon, R. D. and J. T. Miller (1992): Introduced forest trees in New Zealand: recognition, role and seed source. 12. Radiata pine (Pinus radiata D. Don). New Zealand Forest Research Institute Bulletin 124/12.

Burdon, R. D., S. O. Hong and C. J. A. Shelbourne (1997): Progeny $\mathrm{x}$ site interaction in Pinus radiata on nine sites involving three countries, In: Proceedings of the New Zealand forest Research Institute - IUFRO conference: IUFRO 1997 Genetics of Radiata Pine, 1-4 December 1997, Rotorua, N. Z., R. D. BuRdon and J. M. Moore (Eds.). New Zealand Forest Research Institute, Rotorua, N. Z.. 354p. (pp 226-230).

CARson, M. J. (1986): Control-pollinated seed orchards of best general combiners - a new strategy for radiata pine improvement: In: Proceedings of the Plant Breeding Symposium, DSIR, Lincoln, New Zealand, 17-20 February 1986. Agronomy Society of New Zealand Special Publication No. 5. T. A. Williams and G. S. WratT (Eds.). 382p. (pp 144-148).

CARson, S. D. (1991): Genotype x environment interaction and optimal number of progeny test sites for improving Pinus radiata in New Zealand. New Zealand Journal of Forestry Science 21: 32-49.

CARson, S. D. and M. J. CARSON (1986): A breed of radiata pine resistant to Dothistroma needle blight. In: Plant Breeding Symposium DSIR. Agronomy Society of New Zealand Special Publication No. 5. T. A. Williams and G. S. WratT (Eds.). 382p. (pp 202-207).

Cotterill, P. (1986): Breeding strategy: don't underestimate simplicity. In: Proceedings of the IUFRO conference on breeding theory, progeny testing and seed orchards October 13-17, WiLliamsBuRG, V. A., USA. (pp 8-23).

CotTERILL, P. (1989): The nucleus breeding system. Proceedings of the Southern Forest Tree Improvement Conference. 20: $36-42$.

Cotterill, P. P., C. A. Dean, J. CAmeron and M. BrindBERGS (1989): Nucleus breeding: a new strategy for rapid improvement under clonal forestry. In: Breeding tropical trees: population structure and genetic improvement strategies in clonal and seedling forestry; Proceedings of a conference held in Pattaya, Thailand, 28 November-3 December 1988. G. L. Gibson, A. R. GRIFFIN, A. C. MATHESON (Eds.). Winrock International, Arlington. 503p. (pp 39-51).

DANUsEvicius, D. and D. LindGREN (2002): Efficiency of selection based on phenotype, clone and progeny testing in long-term breeding. Silvae Genetica 51: 19-26.

DANusevicius, D. and D. LindGREN (2005): Optimization of breeding population size for long-term breeding. Scandanavian Journal of Forest Research 20: 18-25. 
Dick, M. A. (1998): Pine pitch canker - the threat to New Zealand. New Zealand Forestry, 42: 30-34.

HANOCQ, E., D. BoichaRd and J. L. Foulley (1996): A simulation study of the effect of connectedness on genetic trend. Genetics Selection Evolution, 28: 37-82.

JAYAWICKRAMA, K. J. S. and M. J. CARSON (2000): A breeding strategy for the New Zealand Radiata Pine Breeding Cooperative. Silvae Genetica 49 (2): 82-90.

JAYAWICKRAMA, K. J. S. (2001): Genetic parameter estimates for radiata pine in New Zealand and New South Wales: A synthesis of results. Silvae Genetica 50: 45-53.

JEFFERSON, P. J. (2005): Report on structure of RPBC elite and main breeding populations. Status at 30 March 2005. Confidential report to the Radiata Pine Breeding Consortium No. 170. 115pp.

JEFFERSON, P. A. and S. WEAVER (1997): Gains from clonal testing in the breeding population. In: Proceedings of the New Zealand forest Research Institute - IUFRO conference: IUFRO 1997 Genetics of Radiata Pine, 1-4 December 1997, Rotorua, N. Z., R. D. Burdon and J. M. Moore (Eds.). New Zealand Forest Research Institute, Rotorua, N. Z.. 354p. (pp 226-230).

Johnson, I. G., I. M. Cotterill, C. A. Raymond and M. HENSON (2008): Half a century of Pinus radiata tree improvement in New South Wales. New Zealand Journal of Forestry 52: 7-13.

KInG, J. N., M. J. CARSon and G. R. Johnson (1998): Analysis of disconnected diallel mating designs II results from a third generation progeny test of the New Zealand radiata pine improvement programme. Silvae Genetica 47: 61-76.

KueHN, L. A. (2005): Implications for connectedness in the genetic evaluation of livestock. PhD. Dissertation, Virginia Polytechnic Institute and State University, Blacksburg, Virginia. Pp121. http://scholar.lib.vt.edu/ theses/available/etd-11182005-153403/unrestricted/ Kuehn_Final_Dissertation.pdf.

KUMAR, S. (2006): Correlation between clonal means and OP seedling progeny means, and its implications for radiata pine breeding strategy. Canadian Journal of Forest Research 36: 1968-1975.

KuMAR, S. and T. E. RICHARDSON (2005): Inferring relatedness and heritability using molecular markers in radiata pine. Molecular Breeding 15: 55-64.

Kumar, S., R. J. Spellman, D. J. Garrick, T. E RichardSON, M. LAUsberG and P. L. Wilcox (2000): Multiple marker mapping of wood density loci in an outbred pedigree of radiata pine Theoretical and Applied Genetics 100: 926-933.

Kumar, S., C. L. Echt, P. L. Wilcox and T. E. RichaRdson (2004a): Testing for linkage disequilibrium in the New Zealand radiata pine breeding population Theoretical and Applied Genetics 108: 292-298.

Kumar, S. (2004b) Genetic parameter estimates for wood stiffness, strength internal checking and resin bleeding for radiata pine Canadian Journal of Forestry Research 34: 2601-2610.

Kumar, S., S. Gerber, T. E. Richardson and L. Gea (2005): Testing for non-random contribution of pollens using nuclear- and chloroplast SSR markers in polycross families of Pinus radiata D. Don. Tree Genetics and Genomes DOI 10.1007/s11295-006-0056-y. http:// www.ingentaconnect.com/content/klu/11295/2007/00000 $\underline{003 / 00000003 / 00000056 ? \text { token }=004 \mathrm{~b} 190 \mathrm{ee} 3 \mathrm{~d} 3 \mathrm{~b} 39 \mathrm{dd} 6 \mathrm{e} 5}$ $\underline{86546244044425520355 \mathrm{~d} 7 \mathrm{~d} 703 \mathrm{~b} 70455 \mathrm{e} 4 \mathrm{e} 6 \mathrm{~b} 6340 \mathrm{be} 266}$ 2c5dcdfb9.
Laloë, D., F. Phocas and F. MËnissier (1996): Considerations on measures of precision and connectedness in mixed linear models of genetic evaluation. Genetics Selection Evolution, 28: 359-378.

Lambeth, C, B.-C. Lee, D. O'Malley and N. Wheeler (2001): Polymix breeding with parental analysis of progeny: an alternative to full-sib breeding and testing. Theoretical and Applied Genetics 103: 930-943.

LAVERY, P. B. and D. J. MEAD (1998): Pinus radiata: a narrow endemic from North America takes on the world. In: Ecology and Biogeography of Pinus. D. M. RICHARDSON (Ed.). University Press, Cambridge, United Kingdom. 527 p. (pp 432-439).

Lindgren, D., L. GeA and P. JefFerson (1996): Loss of genetic diversity monitored by status number. Silvae Genetica 45: 52-59.

LstibüReK, M., T. J. Mullin, D. Lindgren and O. RossVALL (2004a): Open-nucleus breeding strategies compared with population-wide positive assortative mating. I. Equal distribution of testing effort. Theoretical and Applied Genetics 109: 1196-1203.

Lstibürek, M., T. J. Mullin, D. Lindgren and O. RossVALL (2004b): Open-nucleus breeding strategies compared with population-wide positive assortative mating. II. Unequal distribution of testing effort. Theoretical and Applied Genetics 109: 1169-1177. DOI 10.1007/s00122-004-1737-2. http://openurl.ingenta.com/ content?genre $=$ article $\&$ issn $=0040-5752 \&$ volume $=$ $109 \&$ issue $=6 \&$ spage $=1169$ \&epage $=1177$.

LstibÜReK, M., T. J. Mullin, Y. A. El-Kassaby (2006): The impact of differential success of somatic embryogenesis on the outcome of clonal forestry programs. I. Initial comparison under multi-trait selection. Canadian Journal of Forest Research 36: 1376-1384.

Machalovich, M. F. and F. E. BRIDGWATER (1989): Modelling elite populations and positive assortative mating in recurrent selection programs for general combining ability. In: Proceedings of the $20^{\text {th }}$ Southern Forest Tree Improvement Conference, Charleston, S. C., USA, 26-30 June 1989. Macon, USA: Southern Forest Tree Improvement Committee. 442p. (pp 43-49).

McKeand, S. E. and F. W. BRIDGWater (1998): A strategy for the third breeding sycle of loblolly pine in the southeastern U.S. Silvae Genetica 47: 223-234.

MARK, T. and P. MASDEN (2002): Bayesian MACE for Eyreshire confirmation traits. http://www-interbull.slu. se/bulletins/bulletin29/Mark.pdf $6 \mathrm{pp}$.

Mathur, P. K., B. J. Sullivan and J. P. Chesnais (2002): Measuring connectedness: concept and application to a large industry breeding programs in Proceedings of $7^{\text {th }}$ World Congress of Genetics Applied to Livestock Production, 32: 545-548.

ORMSBY, M. (2004): Pitch canker in quarantine - a biosecurity success story. Biosecurity 51: 10 .

Powell, M. B., T. A. McRae, H. X. Wu, G. W. Dutkowski and D. J. PILBEAM (2004): Breeding strategy for Pinus radiata in Australia. In: Proceedings of an IUFRO joint conference of Division2 Forest genetics and tree breeding in the age of genomics: Progress and future. 1-5 November, Charleston, South Carolina, USA. 8pp. http://www.stba.com.au/documents/powellPRADstratCharlestonv2.pdf.

Powell, M. B., T. A. McRae, D. J. Pilbeam and H. X. Wu (2005): Progressing radiata pine breeding in Australia. In: Proceedings of the Institute of Foresters of Australia meeting 'Burning issues in forestry' 10-14 April 2005, 
Mount Gambier, South Australia. 8pp. http://www.stba. com.au/documents/ProgressingRadiataPineinAustralia April2005.pdf.

Ribeiro, V. J., R. P. V. Brondani, A. Y. Ciampi and D. GRatTAPAGLIA (1998): Paternity determination of superior OP progenies of Eucalyptus based on microsatellite markers. Genetic Molecular Biology 21: 212.

Rossvall, O., D. LindGren and T. J. Mullin (1998): Sustainability robustness and efficiency of a multi-generation breeding strategy based on within-family clonal selection. Silvae Genetica 47: 307-321.

Rossvall, O. and T. J. Mullin (2003): Positive assortative mating with selection restrictions on group coancestry enhances gain while conserving genetic diversity in long-term forest tree breeding. Theoretical and Applied Genetics 107: 629-642.

Ruotsalainen, S. and D. Lindgren (2000): Stratified sublining: a new option for structuring breeding populations. Canadian Journal of Forestry Research 30: 596-604.

SHAw, D. V. and J. V. Hood (1985): Maximising gain per effort by using clonal replicates in genetic tests. Theoretical and Applied Genetics 71: 392-399.

Shelbourne, C. J. A., R. D. Burdon, S. D. Carson, A. Firth and T. G. Vincent (1986): Development plan for radiata pine breeding. Forest Research Institute, Rotorua, New Zealand. 142pp.

Shelbourne, C. J. A., S. Kumar, R. D. Burdon, L. D. Gea and H. S. Dungey (2007): Deterministic Simulation of Gains for Seedling and Cloned Main and Elite Breeding Populations of Pinus radiata and Implications for Strategy. Silvae Genetica 56: 253-300.

Stovold, G. T. and P. J. JefFerson (2004): 2004 plus tree selections from within the Advanced Generation Dothistroma population trial series (1994) and the High Density Elite trial series (1995). Confidential report to the Radiata Pine Breeding Consortium No. 166. 21pp.

Stovold, G. T., R. D. Burdon and L. D. GeA (2004): Needs and options for managing native-provenance gene resources. Unpublished confidential report to the Radiata Pine Breeding Company No. 150. 27pp.

Thulin, I. J. (1957): Application of tree breeding to forestry in New Zealand. New Zealand Journal of Forestry Science 7: 41-46.
VERRYN, S. D. and C. L. SNEDDEN (2000): Optimising the expected genetic gains of various breeding and selection strategies. In: Proceedings of the international IUFRO conference on Forest Genetics for the Next Millennium, Durban, South Africa, 8-13 October 2000. 260p. (pp 240-243).

White, T. L., G. R. Hodge and G. L. Powell (1993): An advanced-generation tree improvement plan for slash pine in the Southeastern United States. Silvae Genetica 42: 359-371.

White, T. L., A. C. Matheson, P. P. Cotterill, R. G. Johnson, A. F. Rout and D. B. Boomsma (1999): A Nucleus Breeding Plan for Radiata Pine in Australia. Silvae Genetica 48: 122-133.

White, T. L. and M. J. CARson (2004): Breeding programs of conifers. In: Plantation Forest Biotechnology for the $21^{\text {st }}$ Century. T. L. White and M. J. CARson (Eds). Research Signpost, Kerala India 446pp. (pp 61-85).

Wilcox, P. L., T. E. RichaRdson and S. D. CARSON (1997): Nature of quantitative trait variation in Pinus radiata: Insights from QTL detection experiments. In: IUFRO working party S2.02.19 Genetics of radiata pine, Proceedings of an international conference 1-4 December 1997. FRI Bulletin No. 203, New Zealand Forest Research Institute, Rotorua New Zealand. 354p. (pp 304-312).

Wilcox, P. L., C. S. Echt and R. D. Burdon (2007): Geneassisted selection - applications of association genetics for forest tree breeding. In: Association mapping in plants. N. C. Oraguzie, E. H. A. Rikkerink, S. E. GarDINER and H. N. DE Silva (Eds.). Springer Verlag, New York. 277p. DOI 10.1007/978-0-387-36011-9_10

Williams, C. G. and O. SAVOlaineN (1996): Inbreeding depression in conifers: implications for using selfing as a breeding strategy. Forest Science 42: 102-117.

Williams, E. R., A. C. Matheson and C. E. Harwood (2002): Experimental design and analysis for tree improvement. CSIRO publishing, Australia. 224p.

Wu, H. X., A. C. Matheson and D. Spencer (1998): Inbreeding in Pinus radiata. II. Tim course of inbreeding depression and effect on growth curve. New Zealand Journal of Forestry Science 28: 123-139.

Yong-Bi Fu, G., P. Y. Clarke, G. NAmkoong and A. D. YANCHUK (1998): Incomplete block designs for genetic testing: statistical efficiencies of estimating family means. Canadian Journal of Forestry Research 28: 977-986. 